\title{
INTRODUCTION \\ The French Empire and the History of Economic Life
}

\author{
Owen White and Elizabeth Heath
}

\begin{abstract}
This introduction to the dossier "Wine, Economy, and Empire" surveys the place of economic history in the field of French Empire studies over the last twenty years. Drawing upon the concept of "economic life" as defined by William Sewell, the authors argue that a renewed focus on economic activity within the French Empire offers new opportunities to interrogate commonplace ideas about chronology, imperial forms, and structures of power. The article briefly examines some of the specific avenues of inquiry opened by a conception of economic life as socially "embedded," while highlighting recent works that exemplify the possibilities of this approach for scholars of empire.
\end{abstract}

\section{KEYWORDS}

capitalism, economic life, empire, infrastructure, labor

If the past twenty years or so of heightened interest in the history of the French Empire has delivered a satisfactory return on scholarly investment, it seems fair to say that the theme of economic life within that empire has received something of a raw deal. In this respect it is perhaps no different from the historical profession as a whole, at least in the English-speaking world. For, as William Sewell pointed out in a 2010 essay, the historical study of economic life-which Sewell defines broadly (yet aptly) as "the history of human participation in the production, exchange, and consumption of goods"-became an increasingly fugitive presence in mainstream historiography from around $1980 .{ }^{1}$ In a timeframe roughly coincident with the collapse of Marxist regimes (but also a more assertive and expansive capitalism), more and more historians turned away from economic determinism and instead accorded culture far greater power to shape human society and politics. Much of the terrain of economic life was ceded to the ever more technical field of economic history, whose practitioners' quantitative methods and fixation on economic growth left non-adepts unsure

French Politics, Culture \& Society, Vol. 35, No. 2, Summer 2017: 76-88

(C) The Institute of French Studies at New York University and the

Minda de Gunzburg Center for European Studies at Harvard University

doi:10.3167/fpcs.2017.350207 
how to respond or even, frequently, how to read. The revival of French imperial and colonial history that began to take shape in the 1990s therefore occurred when prevailing trends emphasized cultural constructions of human difference (guided by works like Edward Said's Orientalism) rather than economic differences forged by imperialism and colonialism. ${ }^{2}$ Once familiar characters in the dramatis personae of empire-the workers and peasants who constituted the backbone of so many research projects through the 1970s and early 1980s-were more likely to appear as bit players, if at all, while the holders of capital did not get much time in the spotlight either.

This picture is admittedly reductive, and some readers may immediately wish to raise objections. Historians of the eighteenth-century French Empire, for example, might claim uninterrupted engagement with political economy and the workings of commerce, not only in the slavery-marked space dubbed the "Atlantic World" but also on inland frontiers. ${ }^{3}$ The economics of empire, and especially the business of empire, retained a relatively firm toehold (if perhaps no more than that) in France into the 1990s and beyond through the influence of scholars like Catherine Coquery-Vidrovitch, Jacques Marseille, and Hubert Bonin. ${ }^{4}$ It could also be argued that the effacement of economic life in Anglophone scholarship on the modern French Empire was hardly total, ${ }^{5}$ and even that there were some successful attempts to apply approaches from cultural history to matters of economic significance: Alice Conklin's work on the "civilizing mission," for example, illustrated some of the ways a specific discourse had tangible effects on economic life in French-ruled West Africa. ${ }^{6}$ Nevertheless, it seems to us difficult to deny that the past two or three decades of historiography on France's empire after 1830 has not preoccupied itself greatly with how French dominance overseas set the contours of economic activity in colonies and metropole and, in turn, influenced people's lives of work and consumption.

The moment, however, seems ripe for redressing this relative absence. In the years since Sewell's article appeared, there have been signs of renewed interest across the historical profession in the kinds of topics he identified as deficient. Many of the more prominent works in this economic turn fall under the rubric of the history of capitalism, sometimes with an avowedly global field of vision. ${ }^{7}$ Others have explicitly addressed globalization and empire and, particularly, how new technologies and flows of people and goods reshaped metropolitan and imperial economic spaces in the late nineteenth and early twentieth centuries. ${ }^{8}$ Meanwhile, commodity studies have drawn scholarly and popular attention to an array of goods, especially colonial consumables, and the commercial networks and consumption habits that intertwined the fates of producers (often colonial) and consumers (usually metropolitan). ${ }^{9}$

For French Empire specialists seeking to recover "the economic" from the sidelines, these broader trends warrant serious consideration, though with some caveats. The new attention to capitalism, for example, has clear productive potential (and may return us to some older works for ideas). ${ }^{10}$ At the same 
time, the uneven distribution and reach of capital in the nineteenth and twentieth centuries means that a focus on capitalism alone cannot capture the full variety of economic relations that developed within and beyond French imperial space. ${ }^{11}$ Similarly, an emphasis on flows beyond borders must not obscure the fact that nineteenth- and twentieth-century states were explicitly interested in regulating (and had greater capacity to regulate) the movement of people and goods across imperial boundaries. Meanwhile, the study of commodities has great potential to integrate the spheres of production and consumption, but at the risk of the commodities themselves overshadowing human actors and the political and social contexts that shaped supply chains. With these provisos in mind, we seek a more expansive approach that draws together economic concerns with French colonial historiography's abiding interest in constructs of power and cultural and political processes.

We embrace the term "economic life" here because it seems to offer the most open-ended invitation for historians to investigate the social realms of imperial economic experience as well as the full range of institutions and ideologies that enabled or set limits on economic action. It is, in short, the "life" part of economic life that interests us most. This is not to deny a continuing role for the kinds of cost-benefit analyses that economic historians have often favored (and whose value to imperial and colonial historians was recently demonstrated in an article by Elise Huillery in the Journal of Economic History, Sewell's benchmark for trends in the profession). ${ }^{12}$ Nor are we impugning quantitative methods in general; indeed, "digital history" as it develops may provide useful analogs to the kinds of data-mining techniques that seem increasingly prevalent in certain branches of the social sciences. It is, instead, to advocate an approach toward economic history that is attentive to large-scale structural transformation yet remains grounded in local, concrete activities and practices. The history of economic life in our view implies two approaches in particular: first, an effort to keep human actors as close to the center of the frame as possible, whether they are on the move or embedded in specific locations; and second, an understanding that economic activity is socially "embedded" and (in Sewell's words) "governed as much by social ties, cultural assumptions, and political processes ... as by purely 'rational' economic action." ${ }^{13}$ Taken together, these two approaches offer historians of the French Empire an opportunity to interrogate anew ideas about chronology, imperial forms, and structures of power that have become commonplace in the field. In what follows, we briefly point to some of the avenues of inquiry opened by this conception of economic life, while highlighting recent works that exemplify the possibilities it offers.

\section{Rethinking the French Empire in Time and Place}

In the last twenty or so years, historians of the French Empire have settled into a temporal framework defined above all by political processes emanating from 
the metropole and moments of formal imperialism or imperial crisis. When viewed through the lens of economic life, this chronology necessarily retains many familiar contours. Though we may assume that economic life is happening at all times, economic intensification or hardship naturally draws attention toward some historical moments more than others, and for good reason: moments of economic upheaval are routinely accompanied by significant social, political, and cultural transformation. Times of war provide an obvious case in point. In both world wars, a variety of forces drove colonial administrations to increase their extraction of local resources (including labor), and, in turn, set some territories up for more intense "development" after armed conflict ended. ${ }^{14}$ Equally, no historian of empire can write about the 1930s without some consideration of the impact of the Depression. ${ }^{15}$ Nonetheless, a new focus on economic life may redirect attention to periods frequently neglected, such as the wide stretches of the nineteenth century that witnessed the transition from the first to the second wave of French imperialism. To be sure, historians of Algeria and the "old colonies" have long considered the social and political structures linking the two moments of empire. ${ }^{16}$ However, as David Todd has argued, there may be more to French imperial activity between 1814 and 1870 than meets the eye if one is willing to adopt the notion of "informal imperialism" so familiar to British historians of that period and thereby recognize efforts to spread French influence, and not least economic influence, as "imperial." ${ }^{17}$

To some extent one finds a similar type of clustering around particular places and spaces. Studying economic life requires consideration of sites of production, exchange, and consumption. Yet certain sites still tend to attract attention (and yield archival sources) more readily than others: plantations producing cash crops like rubber more than subsistence-oriented smallholdings, port cities more than inland market centers, and (remembering their trade-promoting origins, never entirely lost) colonial exhibitions more than humbler sites of consumption like cafés, bakeries, and market stalls. ${ }^{18}$ The process of contextualizing and establishing the historical importance of even the lowliest place or space, though, can highlight the wide webs of circulation that linked goods, capital, labor, and economic ideas. ${ }^{19}$ These connections often spanned metropole and colony but also extended well beyond those boundaries, pointing to the limits of the metropole-colony dyad as a historical framework and the need to situate the French imperial space within a wider, more "global" context. For, even in moments when the idea of a "colonial pact" that channeled trade between colonies and the metropole acquired new weight (and in some situations looked like a reality), ${ }^{20}$ colonial exchange was rarely if ever purely bidirectional. Algerian and Tunisian alfa or esparto grass was sold to British paper manufacturers, Vietnamese rice consumed in China, and frozen meat from Madagascar purchased in Egypt and Italy. ${ }^{21}$ Similarly, the perfume manufacturers of Grasse, in southern France, sourced a great many of their raw materials from French colonial possessions-lemon- 
grass from the French Congo, benzoin resin from Laos, vanilla beans from Tahiti, and so on-but in the end their resource networks were global in scope, and they made many of their sales beyond France and its empire. ${ }^{22}$ Greater attention to economic life and especially the broad trade networks that connected disparate places therefore promises to make the French Empire look more global and less like a closed circuit.

\section{Reconsidering the Means and Loci of Economic Life}

To understand how Tunisian alfa growers or Grasse perfumers pursued opportunities presented by the wider market requires attending to the economic structures and markets that facilitated-or hindered-these exchanges. Largescale infrastructural projects, technology, financial institutions, and markets clearly played an essential role in shaping imperial commerce, and have received the lion's share of attention. Nonetheless, formal economic structures (and the colonial state that backed them) neither determined the entirety of economic life nor the ways in which individual actors used technologies and institutions for their own purposes. ${ }^{23}$ Analyzing concrete economic activities, particularly in relation to formal mechanisms and avenues of economic exchange, can offer a nuanced understanding of how individual actors engaged in ordinary economic activities contributed to the uneven nature of state authority within the French Empire.

The word "infrastructure" may immediately call to mind forms of transportation commonly associated with modern imperial expansion, such as steam shipping, typically dominated by a few powerful companies or wealthy families, ${ }^{24}$ or railroads, whose workers have provided a focus for some historians. ${ }^{25}$ But non-industrial forms of transport were also economically significant, from the canoes operated by Adouma men that remained essential to movement along the River Ogooué in Gabon well into the twentieth century, to the rickshaws that propelled Europeans and middle-class Vietnamese around cities like Hanoi and Saigon in a similar period. ${ }^{26}$ Alternatively, the word "infrastructure" may evoke what were often state-led projects to manage water via dams or irrigation or to spread power sources like electricity. ${ }^{27}$ At a lower level and on a smaller scale, in contrast, a recent strain of historiography has directed our attention to the ways that colonized people adopted, adapted, or rejected particular technologies either in agriculture or in urban settings (bicycles, sewing machines, typewriters). Users of "everyday" technologies sometimes found a measure of economic empowerment and new productive powers that point to the continued importance of the household as a locus of economic activity and innovation. ${ }^{28}$

Historians can also choose different levels of entry when considering what we might call financial infrastructure. Though the topic of banking and empire tends to revolve around elites, investigation of credit-granting insti- 
tutions or organizations may allow historians to access economic decisionmaking at the grass roots-by Algerian peasants who joined sociétés indigènes de prévoyance, for example, or European colonists in rural Algeria who turned to cooperative lending institutions in pursuit of their goals; indeed, cooperatives and mutual aid societies assumed importance in many colonial settings. ${ }^{29}$ Unions served a similarly useful financial function for a number of colonial workers, including Guadeloupean smallholders seeking greater independence from centralized sugar factories. ${ }^{30}$ Colonialism also affected everyday exchange through efforts to regulate currency, especially as colonial states built their tax-gathering capacity. ${ }^{31}$ French colonial taxation, both the modes of its collection and reactions to its demands, stands out as an understudied topic. ${ }^{32}$

As much as colonial officials and institutions sought to impose their authority and constrain commerce to formal markets and taxable forms of legitimate trade, a great deal of illicit or unregulated business took place around the structures that empire put in place. Charges of speculation, smuggling, illegal dealing, and piracy were often, like charges of treason, a matter of dates, shifting borders, and changing legal regimes. Nowhere were the tensions over what constituted "legitimate" commerce more evident than at the porous boundaries that separated formal colonies from protectorates and mandates within the empire. As Mary Lewis has argued in her work on Tunisia, the border between the protectorate and Algeria offered Tunisians ample opportunity to manipulate colonial ideas of nationality and identity and, in the process, evade onerous tax obligations. ${ }^{33}$ In other cases what the colonial state called smuggling was simply the continuation of old trade across new borders. ${ }^{34}$ While colonial governments were naturally sensitive to any such challenges to their finances and authority, their own economic behavior was sometimes so inimical to local moral economies that it fed the opposition they hoped to avoid. The state's monopolies on alcohol and opium as well as salt in French Indochina represents a particularly good example. The alcohol monopoly, as Gerard Sasges has argued, may have made a significant contribution to the development of the political power of the government-general of Indochina-the monopoly's economic contribution was more ambiguous-but it also inflamed opposition and all but dared local people to break the law and produce the rice alcohol they wanted. ${ }^{35}$ Not all colonial interventions so obviously warped local economic life, and, moreover, one can certainly find examples of colonized people taking advantage of new (if often fleeting) economic opportunities, either in spite of or in interaction with the colonial state. ${ }^{36}$ Yet French colonial systems of rule and law were always subject to the charge that what they prescribed as legitimate economic behavior was at best questionable and at worst unfounded on any legitimacy at all. 


\section{Placing People and Networks in an Imperial Context}

It is clear, then, that individuals across the empire routinely circumvented expectations about how they should act economically, with important consequences for how colonialism operated at the ground level. By expanding the framework in which we situate "economic" activity—and challenging assumptions that the economic, political, or cultural can be treated as discrete realms of activity-the study of economic life opens new perspectives on the people who inhabited the French Empire, the networks that connected them (however tenuously), and the conditions (rarely of their own choosing) under which they made their lives and livelihoods.

That the state played a significant role in shaping people's economic behavior is obvious, and especially so in the case of labor regimes across the empire. Here the state intervened in multiple ways, for example by overseeing forced labor, ${ }^{37}$ policing free labor at moments of conflict, ${ }^{38}$ or simply by employing an array of white-collar workers for its everyday needs. ${ }^{39}$ At the same time, the state's influence over labor patterns extended far beyond the marketplace. As Charles Hirschman has argued in reference to British Malaya, "the political and economic framework sponsored by imperialism" helped underwrite the construction of racial ideologies that in turn did much to determine ethnic preferences for particular types of labor. ${ }^{40}$ In this way a political economy of race fed into the elaboration of myths about the supposedly in-built aptitudes of Kabyle workers vis-à-vis those of Arabs in Algeria and the superiority of Indian indentured laborers relative to freed slaves in post-emancipation Guadeloupe and Martinique. ${ }^{41}$

Although a major figure in the labor market, the colonial state nevertheless was only one factor shaping employment patterns. Some of the best studies of labor and empire have focused on labor migration, either within colonial territories or, especially after World War I, in France as well. This scholarship has demonstrated the statistical over-representation of certain populations in the supply of colonial labor, such as the Soninke of West Africa. ${ }^{42}$ Studies of migrating workers, to which one might also add trade diasporas like that of the Lebanese (or Libano-Syriens, in colonial-era parlance), ${ }^{43}$ all depend in some sense on uncovering the networks that helped people acquire what the South African labor historian Charles van Onselen termed "market intelligence"-in essence, the knowledge or confidence that a particular move represented a good economic prospect. ${ }^{44}$ Though the social and institutional contexts may be very different, this emphasis on networks and knowledge is equally prominent in histories of the imperial dealings of the patronat or business community. ${ }^{45}$ Records of chambers of commerce or annual company reports are among the sources that can help historians investigate the kinds of human connections that facilitated capital flows and shaped employment needs. ${ }^{46}$

Colonial "labor," of course, took many forms, not all of which fell under the typical rubric of wage labor. Colonial agents, for example, represented 
another kind of labor force whose economic activities held significant import for the way colonial rule worked in practice. A key objective of the recent wave of scholarship on the French Empire has been to seek a better knowledge of the colonialists-the social worlds they came from and created overseas, their habits of mind, the understandings they developed of the peoples they ruled. ${ }^{47}$ This interest among historians has increasingly extended to non-state actors, with a burgeoning literature on French missionaries representing one good example. ${ }^{48}$ Greater attention to economic life can help with this process; indeed, the economic impact of missionaries themselves-if not also indigenous religious movements-merits fuller study. ${ }^{49}$ But surely there are countless opportunities to expand upon the range of actors and contexts for economic activity that historians have often seemed to favor (male, urban, migratory).

The two essays presented below both focus on a specific commodity, wine, in relation to a specific part of the empire, Algeria. Each essay reveals ways in which economic activity in Algeria was also woven into the economic lives of many residents of the metropole, though the ambiguity of Algeria's "imperial" status often made this relationship contentious. Elizabeth Heath examines how the wine crisis of 1907 brought wine producers based in the Midi and Algeria into conflict, ultimately mobilizing the southern metropolitan population to seek new regulations of imperial trade based on the idea that Midi wine was a cultural rather than an economic commodity, and thus deserving of state protection. Owen White shows how a technological innovation in the transportation of wine in the 1930s provoked labor conflict as well as some unexpected alliances both within and across multiple port cities in Algeria and France. In revealing some of the "social ties, cultural assumptions, and political processes" that shaped the operation of Algeria's wine industry and metropolitan responses to it, both of these two essays call attention to the socially embedded nature of imperial economic activity and hope to contribute to a renewed historical emphasis on the economic life of the French Empire.

OWEN WHITE is an associate professor of history at the University of Delaware. He is currently completing a history of Algeria's wine industry. E-mail: owhite@udel.edu

Elizabeth Heath is an assistant professor of history at Baruch College-CUNY. She is the author of Wine, Sugar, and the Making of Modern France: Global Crisis and the Racialization of French Citizenship, which received the Alf Andrew Heggoy Prize from the French Colonial Historical Society in 2015. She is currently working on a new project that explores the role that empire and colonial commerce played in shaping modern French economic, cultural, and social life. E-mail: Elizabeth.Heath@baruch.cuny.edu 


\section{Notes}

1. William H. Sewell, Jr., "A Strange Career: The Historical Study of Economic Life," History and Theory 49 (2010): 146-166.

2. For an incisive survey of the field of colonial history between 1951 and 2001, see Frederick Cooper, Colonialism in Question: Theory, Knowledge, History (Berkeley: University of California Press, 2005), 33-55.

3. For example, John Garrigus, "Blue and Brown: Contraband Indigo and the Rise of a Free Colored Planter Class in French Saint-Domingue," The Americas 50, 2 (1993): 233-263; David Geggus, "Sugar and Coffee Cultivation in Saint Domingue and the Shaping of the Slave Labor Force," in Cultivation and Culture: Labor and the Shaping of Slave Life in the Americas, ed. Ira Berlin and Philip Morgan (Charlottesville: University of Virginia Press, 1993); Arthur Stinchcombe, Sugar Island Slavery in the Age of Enlightenment: The Political Economy of the Caribbean World (Princeton: Princeton University Press, 1995); Daniel H. Usner, Jr., Indians, Settlers, and Slaves in a Frontier Exchange Economy: The Lower Mississippi Valley before 1783 (Chapel Hill: University of North Carolina Press, 1992); James F. Searing, West African Slavery and Atlantic Commerce: The Senegal River Valley, 1700-1860 (Cambridge: Cambridge University Press, 1993).

4. Notable works include Jacques Marseille, Empire colonial et capitalisme français: Histoire d'un divorce (Paris: Albin Michel, 1984); Hubert Bonin, Catherine Hodeir, and Jean-François Klein, eds., L'Esprit économique impérial (1830-1970): Groupes de pression et réseaux du patronat colonial en France et dans l'empire (Paris: Société française d'histoire d'outre-mer, 2008); Catherine Hodeir, Stratégies d'empire: Le grand patronat colonial face à la décolonisation (Paris: Belin, 2003); Daniel Lefeuvre, Chère Algérie: La France et sa colonie 1930-1962 (Paris: Flammarion, 2005).

5. Martin Thomas has consistently been sensitive to economic questions; see, for example, The French Empire between the Wars: Imperialism, Politics, and Society (Manchester: Manchester University Press, 2005).

6. Alice L. Conklin, A Mission to Civilize: The Republican Idea of Empire in France and West Africa, 1895-1930 (Stanford: Stanford University Press, 1997), for example 38-72. Other important Anglophone contributions from the 1990s include Richard L. Roberts, Two Worlds of Cotton: Colonialism and the Regional Economy in the French Soudan, 1800-1946 (Stanford: Stanford University Press, 1996), and parts of David Prochaska, Making Algeria French: Colonialism in Bône, 1870-1920 (Cambridge: Cambridge University Press, 1990).

7. See, for example, Sven Beckert, Empire of Cotton: A Global History (New York: Alfred A. Knopf, 2014); Edward E. Baptist, The Half Has Never Been Told: Slavery and the Making of American Capitalism (New York: Basic Books, 2014); and, for a survey of the field, Larry Neal and Jeffrey G. Williamson, eds., The Cambridge History of Capitalism, 2 vols. (Cambridge: Cambridge University Press, 2014).

8. See, for example, Gary Magee and Andrew Thompson, Empire and Globalisation: Networks of People, Goods and Capital in the British World, c. 1850-1914 (Cambridge: Cambridge University Press, 2010); Sebastian Conrad, Globalisation and the Nation in Imperial Germany (Cambridge: Cambridge University Press, 2010).

9. For a sense of the scholarly work in this field, see Jonathan Curry-Machado, ed., Global Histories, Imperial Commodities, Local Interactions (Basingstoke: Palgrave Macmillan, 2013).

10. Catherine Coquery-Vidrovitch, Le Congo au temps des grandes compagnies concessionnaires 1898-1930 (Paris: Mouton \& Co., 1972); Martin J. Murray, The Development of Capitalism in Colonial Indochina (1870-1940) (Berkeley: University of California Press, 1980); Patrick Manning, Slavery, Colonialism and Economic Growth in Dahomey, 1640-1960 (Cambridge: Cambridge University Press, 1982). 
11. See Cooper's discussion of the term "globalization" in Colonialism in Question, 91-112.

12. Elise Huillery, "The Black Man's Burden: The Cost of Colonization of French West Africa," Journal of Economic History 74, 1 (2014): 1-38. Prior to this the JEH had not published an article focused on the French Empire since Edward Peter Fitzgerald, "Did France's Colonial Empire Make Economic Sense? A Perspective from the Postwar Decade, 1946-1956," Journal of Economic History 48, 2 (1988): 373-385.

13. Sewell, "A Strange Career," 157. The concept of "embeddedness" is most closely associated with the economic historian Karl Polanyi and the sociologist Mark Granovetter.

14. On World War Two, for example, see Eric T. Jennings, Free French Africa in World War II: The African Resistance (New York: Cambridge University Press, 2015), 175-248; Martin Thomas, "Resource War, Civil War, Rights War: Factoring Empire into French North Africa's Second World War," War in History 18, 2 (2011): 225-248; Benjamin Freud, "Organizing Autarky: Governor General Decoux's Development of a Substitution Economy in Indochina as a Means of Promoting Colonial Legitimacy," Sojourn: Journal of Social Issues in Southeast Asia 29, 1 (2014): 96-131.

15. For a useful overview of the Depression in one territory, see Pierre Brocheux and Daniel Hémery, Indochina: An Ambiguous Colonization (Berkeley: University of California Press, 2009), 250-280.

16. See Jennifer Sessions, By Sword and Plow: France and the Conquest of Algeria (Ithaca: Cornell University Press, 2011); Myriam Cottias, "Mariage et citoyenneté dans les Antilles françaises $\left(\mathrm{XVII}^{\mathrm{e}}-\mathrm{XX} \mathrm{C}^{\mathrm{e}}\right)$ : de l'esclave à la femme 'poto-mitan'," in Construire l'histoire antillaise: Mélanges offerts à Jacques Adélaïde-Merlande, ed. Lucien Abenon, Danielle Bégot, and Jean-Pierre Sainton (Paris: Éditions du CTHS, 2002); Hilary Jones, The Métis of Senegal: Urban Life and Politics in French West Africa (Bloomington: Indiana University Press, 2013).

17. David Todd, “A French Imperial Meridian, 1814-1870," Past and Present 210 (2011): 155-186; idem, "Transnational Projects of Empire in France, c.1815-c.1870," Modern Intellectual History 12, 2 (2015): 265-293. On this period see also Jenna Nigro, "Colonial Logics: Agricultural, Commercial, and Moral Experiments in the Making of French Senegal, 1763-1870" (PhD dissertation, University of Illinois at Chicago, 2014); Benoît Joachim, "Commerce et décolonisation: l'expérience franco-haïtienne au XIX ${ }^{e}$ siècle," Annales. Histoire, sciences sociales 27, 6 (1972): 1497-1525.

18. On plantations, for example, Martin J. Murray, "White Gold' or 'White Blood'? The Rubber Plantations of Colonial Indochina, 1910-1940," Journal of Peasant Studies 19, 2 (1992): 41-67, and Pierre Brocheux, "Le prolétariat des plantations d’hévéas au Vietnam méridional: aspects sociaux et politiques (1927-1937)," Le Mouvement social 90 (1975): 55-86; on ports, Jean-François Klein and Bruno Marnot, eds., Les Européens dans les ports en situation coloniale (Rennes: Presses universitaires de Rennes, 2015); on exhibitions, Lauren Janes, "The Taste of Empire: Colonial Food in Interwar Paris" (PhD dissertation, University of California-Los Angeles, 2011), 311-379.

19. Jean-François Klein similarly emphasizes circulation in "Du patronat colonial au patronat impérial: un changement de paradigme," Vingtième siècle. Revue d'histoire 114, 2 (2012), 75.

20. See, for example, Samir Saul, "Les pouvoirs publics métropolitains face à la Dépression: la Conférence économique de la France métropolitaine et d'Outre-mer (1934-1935)," French Colonial History 12 (2011): 167-191; Catherine Boone, Merchant Capital and the Roots of State Power in Senegal 1930-1985 (Cambridge: Cambridge University Press, 1992), 31-77.

21. Gavin McQuarrie, "European Influence and Tribal Society in Tunisia during the Nineteenth Century: The Origins and Impact of the Trade in Esparto Grass, 
1870-1940" (PhD dissertation, University of Durham, UK, 1995); Brocheux and Hémery, Indochina, 176-177; Susanne Freidberg, Fresh: A Perishable History (Cambridge, MA: Belknap Press, 2010), 81-83.

22. Eliane Perrin, L'Âge d'or de la parfumerie à Grasse d'après les archives Chiris (1768-1967) (Aix-en-Provence: Edisud, 1996).

23. The concept of the market itself was interpreted differently in different colonial situations. See Megan Vaughan, "The Character of the Market: Social Identities in Colonial Economies," Oxford Agrarian Studies 24, 1 (1996): 61-77.

24. Olivier Boudot, Les Schiaffino, une dynastie d'armateurs (Toulouse: Pascal Galodé, 2008).

25. Jim Jones, Industrial Labor in the Colonial World: Workers of the Chemin de Fer DakarNiger, 1881-1963 (Portsmouth, NH: Heinemann, 2002); David W. Del Testa, "Workers, Culture, and the Railroads in French Colonial Indochina, 1905-1936," French Colonial History 2 (2002): 181-198.

26. Jeremy Rich, "Riding the Currents of Colonialism: Adouma Canoe Workers and French Rule in Gabon, c.1890-1920," Journal of Transport History 32, 1 (2011): 83-105; H. Hazel Hahn, "The Rickshaw Trade in Colonial Vietnam, 1883-1940," Journal of Vietnamese Studies 8, 4 (2013): 47-85.

27. Sara B. Pritchard, "From Hydroimperialism to Hydrocapitalism: 'French' Hydraulics in France, North Africa, and beyond," Social Studies of Science 42, 4 (2012): 591-615; Simon Jackson, "Mandatory Development: The Political Economy of the French Mandate in Syria and Lebanon, 1915-1939" (PhD dissertation, New York University, 2009), chap. 3, 4, and 5, 115-318.

28. See the special edition on "Everyday Technology in South and Southeast Asia" in Modern Asian Studies 46, 1 (2012), including Michitake Aso, "Profits or People? Rubber Plantations and Everyday Technology in Rural Indochina" (19-45); David Arnold and Erich DeWald, "Cycles of Empowerment? The Bicycle and Everyday Technology in Colonial India and Vietnam," Comparative Studies in Society and History 53, 4 (2011): 971-996; Laura Ann Twagira, “'Robot Farmers' and Cosmopolitan Workers: Technological Masculinity and Agricultural Development in the French Soudan (Mali), 1945-1968," Gender and History 26, 3 (2014): 459-477.

29. On banks, see for example Marc Meuleau, Des pionniers en Extrême-Orient: Histoire de la Banque de l'Indochine, 1875-1975 (Paris: Fayard, 1990); Hubert Bonin, Un outremer bancaire méditerranéen: Histoire du Crédit Foncier d'Algérie et de Tunisie (1880-1997) (Paris: Publications de la SFHOM, 2004); Mohamed Lazhar Gharbi, Crédit et discrédit de la Banque d'Algérie (seconde moitié du XIXe siècle) (Paris: L'Harmattan, 2005). On rural credit in Algeria, see André Nouschi's classic Enquête sur le niveau de vie des populations rurales constantinoises, de la conquête jusqu'en 1919: Essai d'histoire économique et sociale (Paris: Presses universitaires de France, 1961) and Jacques Bouveresse, Un parlement colonial? Les Délégations financières algériennes 1898-1945, 2 vols. (Mont-Saint-Aignon: Publications des Universités de Rouen et du Havre, 2008/2010), II, 158-192.

30. Alain Buffon, "L'affaire Zevallos: une expérience d'autogestion en Guadeloupe au début du siècle," Bulletin de la Société d'histoire de la Guadeloupe 95-8, 1-4 (1993): 41-77.

31. Mahir Şaul, "Money in Colonial Transition: Cowries and Francs in West Africa," American Anthropologist 106, 1 (2004): 71-84. Also Christian Schnakenbourg, "La Banque de la Guadeloupe et la crise de change (1895-1904): loi de l'usine ou loi du marché?" Bulletin de la Société d’histoire de la Guadeloupe 87-90, 1 (1991): 31-95.

32. Laurent Manière, "Popular Unrest and the Press Campaign against the Capitation Tax in Dahomey, 1929-1935," Journal of Policy History 25, 3 (2013): 385-403. For a recent study in the British Empire, see Leigh A. Gardner, Taxing Colonial Africa: The Political Economy of British Imperialism (Oxford: Oxford University Press, 2012), and 
for alternative avenues John Butcher and Howard Dick, eds., The Rise and Fall of Revenue Farming: Business Elites and the Emergence of the Modern State in Southeast Asia (Basingstoke: Macmillan, 1993).

33. Mary Dewhurst Lewis, Divided Rule: Sovereignty and Empire in French Tunisia, 1881-1938 (Berkeley: University of California Press, 2014).

34. Paul Nugent, Smugglers, Secessionists, and Loyal Citizens on the Ghana-Togo Frontier: The Life of the Borderlands since 1914 (Athens, OH: Ohio University Press, 2002).

35. Gerard Sasges, "State, Enterprise and the Alcohol Monopoly in Colonial Vietnam," Journal of Southeast Asian Studies 43, 1 (2012): 133-157; also Erica J. Peters, Appetites and Aspirations in Vietnam: Food and Drink in the Long Nineteenth Century (Lanham, MD: AltaMira Press, 2012); and on opium, Chantal Descours-Gatin, Quand l'opium finançait la colonisation en Indochine: L'élaboration de la régie générale de l'opium (1860-1914) (Paris: L'Harmattan, 1992). For an application of the concept of "moral economy" to a French colonial context, see Van Nguyen-Marshall, "The Moral Economy of Colonialism: Subsistence and Famine Relief in French Indo-China, 1906-1917," International History Review 27, 2 (2005): 237-258.

36. Emily Lynn Osborn, "'Rubber Fever,' Commerce and French Colonial Rule in Upper Guinée, 1890-1913," Journal of African History 45, 3 (2004): 445-465; David H. Groff, "Carrots, Sticks, and Cocoa Pods: African and Administrative Initiatives in the Spread of Cocoa Cultivation in Assikasso, Ivory Coast, 1908-1920," International Journal of African Historical Studies 20, 3 (1987): 401-416; Jeremy Rich, "Forging Permits and Failing Hopes: African Participation in the Gabonese Timber Industry, ca. 1920-1940," African Economic History 33 (2005): 149-173.

37. Babacar Fall, Le Travail forcé en Afrique Occidentale Française (1900-1945) (Paris: Karthala, 1993); Frederick Cooper, Decolonization and African Society: The Labor Question in French and British Africa (Cambridge: Cambridge University Press, 1996).

38. Martin Thomas, Violence and Colonial Order: Police, Workers, and Protest in European Colonial Empires, 1918-1940 (Cambridge: Cambridge University Press, 2012). On labor in Algeria, see René Gallissot, La République française et les indigènes: Algérie colonisée, Algérie algérienne (1870-1962) (Paris: Les Éditions de l'Atelier, 2006).

39. Paul Sager, "Indigenizing Indochina: Race, Class, and the French Colonial Employer-State, 1848-1945" (PhD dissertation, New York University, 2014); Benjamin N. Lawrance, Emily Lynn Osborn, and Richard L. Roberts, eds., Intermediaries, Interpreters, and Clerks: African Employees in the Making of Colonial Africa (Madison: University of Wisconsin Press, 2006); Michelle Pinto, "Employment, Education, and the Reconfiguration of Empire: Africanization in Postwar West Africa" (PhD dissertation, New York University, 2013).

40. Charles Hirschman, "The Making of Race in Colonial Malaya: Political Economy and Racial Ideology," Sociological Forum 1, 2 (1986): 330-361; quotation at 348.

41. Patricia M. E. Lorcin, Imperial Identities: Stereotyping, Prejudice and Race in Colonial Algeria (London: I.B. Tauris, 1995), 46-47; David Northrup, "Indentured Indians in the French Atlantic," Revue française d'histoire d'Outre-mer 87, 326-27 (2000): 245-271; Céline Flory, "New Africans in the Postslavery French West Indies and Guyana, 1851-1889: Close Encounters," in Paths of the Atlantic Slave Trade: Intersections, Identities, and Images, ed. A. Araujo (Amherst, MA: Cambria, 2011).

42. François Manchuelle, Willing Migrants: Soninke Labor Diasporas, 1848-1960 (Athens, OH: Ohio University Press, 1997). See also Dennis D. Cordell, Joel W. Gregory, and Victor Piché, Hoe and Wage: A Social History of a Circular Migration System in West Africa (Boulder: Westview Press, 1996); and on Kabyle migrant labor, Neil MacMaster, Colonial Migrants and Racism: Algerians in France, 1900-1962 (Basingstoke: Macmillan, 1997), 34-49.

43. Andrew Arsan, Interlopers of Empire: The Lebanese Diaspora in Colonial French West Africa (Oxford: Oxford University Press, 2014). 
44. Charles van Onselen, Chibaro: African Mine Labour in Southern Rhodesia, 1900-1933 (London: Pluto Press, 1976), 234-237.

45. Bonin, Hodeir, and Klein, eds., L'Esprit économique impérial, offers many good examples.

46. To cite a few examples, the Archives nationales du monde du travail in Roubaix, the Banque d'Algérie records at the Archives nationales d'Outre-Mer in Aix-enProvence, and the archives of the Chambre de Commerce de Marseille all contain a rich array of sources for the study of these themes.

47. See for example Martin Thomas, ed., The French Colonial Mind, 2 vols. (Lincoln: University of Nebraska Press, 2011).

48. For a sense of the field, see Owen White and J. P. Daughton, eds., In God's Empire: French Missionaries and the Modern World (New York: Oxford University Press, 2012).

49. Claude Prudhomme, "Le missionnaire et l'entrepreneur dans les colonies françaises," in L'Esprit économique impérial, ed. Bonin, Hodeir, and Klein, 149-165. For a discussion of the economic behavior of a non-Christian religious organization (the Murid brotherhood in Senegal), see James F. Searing, "God Alone Is King": Islam and Emancipation in Senegal. The Wolof Kingdoms of Kajoor and Bawol, 1859-1914 (Portsmouth, NH: Heinemann, 2002), xxix-xxxii, 231-267. 